\title{
The Role of Dopamine Receptors in the Neurobehavioral Syndrome Provoked by Activation of L-Type Calcium Channels in Rodents
}

\author{
Suhail Kasim ${ }^{a}$ Bonita L. Blake ${ }^{b}$ Xueliang Fan ${ }^{a}$ Elena Chartoff ${ }^{c}$ \\ Kiyoshi Egami $^{a}$ George R. Breese ${ }^{b}$ Ellen J. Hess ${ }^{a}$ H.A. Jinnah ${ }^{a}$ \\ ${ }^{a}$ Department of Neurology, Johns Hopkins University, Baltimore, Md., ' Department of Psychiatry, \\ University of North Carolina School of Medicine, Chapel Hill, N.C., ${ }^{c}$ Department of Psychiatry, \\ Harvard Medical School, McLean Hospital, Belmont, Mass., USA
}

\section{Key Words}

L-type calcium channel - Dopamine receptors ·

Dystonia $\cdot$ Self-injurious behavior

\begin{abstract}
In rodents, activation of L-type calcium channels with \pm BayK 8644 causes an unusual behavioral syndrome that includes dystonia and self-biting. Prior studies have linked both of these behaviors to dysfunction of dopaminergic transmission in the striatum. The current studies were designed to further elucidate the relationship between \pm BayK 8644 and dopaminergic transmission in the expression of the behavioral syndrome. The drug does not appear to release presynaptic dopamine stores, since microdialysis of the striatum revealed dopamine release was unaltered by \pm BayK 8644 . In addition, the behaviors were preserved or even exaggerated in mice or rats with virtually complete dopamine depletion. On the other hand, pretreatment of mice with $D_{3}$ or $D_{1 / 5}$ dopamine receptor antagonists attenuated the behavioral effects of \pm BayK 8644, while pretreatment with $D_{2}$ or $D_{4}$ antagonists had no effect. In $D_{3}$ receptor knockout mice, \pm BayK 8644 elicited both dystonia and self-biting, but these behaviors were less severe than in matched
\end{abstract}

controls. In $D_{1}$ receptor knockout mice, behavioral responses to \pm BayK 8644 appeared exaggerated. These results argue that the behavioral effects of \pm BayK 8644 are not mediated by a presynaptic influence. Instead, the behaviors appear to result from a postsynaptic activation of the drug, which does not require but can be modified by $D_{3}$ or $D_{1 / 5}$ receptors.

Copyright $(2006$ S. Karger AG, Basel

\section{Introduction}

In mice, administration of the dihydropyridine analog \pm BayK 8644 causes a motor syndrome characteristic of dystonia with slow, stiff and twisting movements [Jinnah et al., 2000]. In young mice, it also causes stereotypical self-biting (SB) [Jinnah et al., 1999b]. The mechanisms by which this drug causes these unusual behaviors remain unknown, but several lines of evidence have indicated they reflect the drug's ability to activate L-type voltageregulated calcium channels $\left(\mathrm{Ca}_{\mathrm{V}} 1.2\right.$ and $\left.\mathrm{Ca}_{\mathrm{V}} 1.3\right)$. The behavioral manifestations emerge after treatment with the $(-)$ BayK 8644 enantiomer that is known to activate these channels, but not after the inactive (+) BayK 8644 enantiomer. The behavioral syndrome also can be reproduced

\section{KARGER}

(ㄷ) 2006 S. Karger AG, Basel

Fax +41613061234

E-Mail karger@karger.ch

www.karger.com
Accessible online at: www.karger.com/dne
H.A. Jinnah, MD, $\mathrm{PhD}$

Meyer Room 6-181, Department of Neurology

Johns Hopkins University

Baltimore, MD 21287 (USA)

Tel. +1 410614 6551, Fax +1 410502 6737, E-Mail hjinnah@jhmi.edu 
with a structurally dissimilar nondihydropyridine activator of L-type calcium channels, FPL 64176. The behaviors provoked with \pm BayK 8644 can be prevented by pretreatment with L-type calcium channel blockers such as nifedipine, nimodipine, or nitrendipine. Finally, the behavioral syndrome is absent from knockout mice carrying a mutation of the cacnald gene, which results in null activity of $\mathrm{Ca}_{\mathrm{V}} 1.2$ channels [Sinnegger-Brauns et al., 2004]. Taken together, these observations provide strong evidence that dystonia and SB with \pm BayK 8644 emerge after activation of these L-type calcium channels.

There are several reasons to suspect the behavioral syndrome results from activation of L-type channels associated with the striatal dopamine pathways. The influence of \pm BayK 8644 on regional brain activity was recently delineated by mapping the induction of the immediate-early gene c-fos [Jinnah et al., 2004]. Despite the nearly ubiquitous expression of L-type calcium channels in the brain, these functional mapping studies revealed a heterogeneous effect on regional brain activity, with the most prominent changes in the striatum. In addition, coadministration of drugs that augment dopaminergic transmission, such as amphetamine or GBR-12909, exaggerate stereotypical SB in response to \pm BayK 8644 [Kasim and Jinnah, 2003]. On the other hand, pretreatment with drugs that deplete dopamine stores, such as reserpine or tetrabenazine, attenuate SB [Kasim and Jinnah, 2003].

An influence of \pm BayK 8644 on striatal dopaminergic systems is consistent with studies from other animal and human studies that have linked dystonia with dysfunction of striatal dopaminergic pathways [Berardelli et al., 1998; Perlmutter and Mink, 2004]. For example, dystonia is a prominent feature of dopa-responsive dystonia, which results from inherited deficiency of dopamine synthesis [Nygaard et al., 1991; Ichinose et al., 1994]. Dystonia also occurs in degenerative disorders affecting dopaminergic pathways, such as Parkinson disease [Nausieda et al., 1980; Jankovic, 2005a]. Finally, dopamine replacement therapies and dopamine receptor antagonists both can cause dystonia under certain circumstances [Jankovic, 2005b; Skidmore and Reich, 2005]. The mechanism by which a defect of dopaminergic transmission might cause dystonia is unknown but it is hypothesized to result from an imbalance or poor coordination of opposing stimulatory and inhibitory motor output from the striatum [Berardelli et al., 1998; Mink, 2003].

Other studies also have linked self-injurious behaviors with abnormalities of dopaminergic transmission [Visser et al., 2000; Schroeder et al., 2001]. SB and self-injurious biting (SIB) occur after large doses or repeated administration of drugs that promote dopamine release, such as amphetamine [Brien et al., 1977; Mueller et al., 1982; Lara-Lemus et al., 1997], methamphetamine [Kita et al., 2000; Shishido et al., 2000; Halladay et al., 2003], or pemoline [Mueller and Nyhan, 1982; Mueller et al., 1986; King et al., 1995; Cromwell et al., 1999; Turner et al., 1999]. They also emerge after repeated administration of high doses of the dopamine reuptake blocker, GBR-12909 [Sivam, 1995; Loupe et al., 2002]. Finally, they are seen consistently after dopamine agonist treatment in rats that had 6-hydroxydopamine (6OHDA) lesions of dopamine pathways in the neonatal period [Breese et al., 1984a, b, 1990, 1994; Moy et al., 1997]. The mechanisms leading to SIB are hypothesized to result from excessive presynaptic release of the transmitter and/or overstimulation of supersensitive postsynaptic receptors [Jinnah et al., 1990; Visser et al., 2000; Schroeder et al., 2001].

The mechanisms by which the L-type channels might interact with dopaminergic pathways to cause dystonia and SB remain uncertain. Two prior studies have suggested that activation of L-type calcium channels with \pm BayK 8644 stimulates a massive release of presynaptic dopamine stores [Watanabe et al., 1998; Okita et al., 2000]. Other studies have shown \pm BayK 8644 to stimulate dopamine release from striatal synpatosomes, slices of striatum in vitro, and cultured midbrain dopamine neurons [Nordstrom et al., 1986; Woodward and Leslie, 1986; Woodward et al., 1988; Chaudieu et al., 1992]. The L-type calcium channel also interacts with postsynaptic striatal dopamine receptors to exert a number of physiological effects. For example, $\mathrm{D}_{1}$ dopamine receptor agonists increase while $\mathrm{D}_{2}$ dopamine receptor agonists decrease calcium currents carried by L-type calcium channels in subpopulations of striatal medium spiny neurons [Surmeier et al., 1995; Hernandez-Lopez et al., 2000]. The ability of dopamine to augment glutamate transmission via NMDA receptors in striatal medium spiny neurons also depends partly on an L-type calcium current [Florez-Hernandez et al., 2002]. Additionally, $\mathrm{D}_{2}$ receptor-mediated suppression of calcium oscillations in midbrain dopamine neurons and $\mathrm{D}_{5}$ receptor-mediated burst firing of subthalamic neurons both are mediated by an L-type calcium channel [Yasumoto et al., 2004]. These findings suggest that the behavioral syndrome associated with \pm BayK 8644 could reflect a presynaptic or postsynaptic mechanism. The purpose of the present studies was to further delineate the role of dopaminergic systems in the expression of the behavioral syndrome provoked by \pm BayK 8644 . 


\section{Methods}

\section{Drugs}

The \pm BayK 8644, GR-103691, L-741,626, L-745,870, SCH23390, SKF-83566, U-99194, and 6OHDA were obtained from Sigma-RBI (St. Louis, Mo., USA). The \pm BayK 8644 was prepared as previously described [Jinnah et al. 1999b, 2000]. Briefly, stock solutions of $10 \mathrm{mg} / \mathrm{ml}$ were first dissolved in a mixture containing equal parts of ethanol and Tween- 80 and stored in amber vials at $4^{\circ} \mathrm{C}$ for up to 1 month. The stock was freshly diluted with distilled water immediately before it was used. The remaining drugs were freshly dissolved in distilled water or saline. All drugs were injected in a total volume of $10 \mathrm{ml} / \mathrm{kg}$.

\section{Normal and Mutant Mice}

Normal C57BL/6J mice were obtained from the Jackson Laboratories (Bar Harbor, Me., USA) and bred and maintained at Johns Hopkins University in groups of 2-12. The dopamine-deficient (DD) mice were bred and maintained at the University of Washington in Seattle, as previously described [Kim et al., 2000; Chartoff et al., 2001]. These mice were generated by genetic deletion of the endogenous tyrosine hydroxylase $(T h)$ gene, with a subsequent targeting of the Th gene to the dopamine beta-hydroxylase ( $D b h$ ) locus. These $\mathrm{Th}^{-/} ; \mathrm{Dbh}^{\mathrm{Th} /+}$ mice (DD mice) exhibit severe dopamine loss without norepineprhine or epinephrine loss. Mice carrying a mutation in the $\mathrm{D}_{3}$ dopamine receptor $\left(\mathrm{D}_{3}\right.$ knockouts) were obtained from Jackson Laboratories and bred at Johns Hopkins University along with strain-matched controls. Mice carrying a mutation in the $\mathrm{D}_{1}$ dopamine receptor ( $\mathrm{D}_{1}$ knockouts) were kindly supplied by Richard Mailman (University of North Carolina, Chapel Hill, N.C.) and bred along with strain-matched controls. Both male and female mice were evaluated after weaning at 4-5 weeks of age.

All animals had free access to food and water at all times. All procedures were conducted in accordance with guidelines described by the National Institutes of Health Guide for Care and Use of Laboratory Animals and the Animal Care and Use Committee of the appropriate institution.

\section{Microdialysis}

Microdialysis of the striatum was performed to determine if \pm BayK 8644 induced dopamine release in mice. Concentric microdialysis probes were prepared as previously described [Page et al., 2003]. Briefly, a fused silica tube with $149 \mu \mathrm{m}$ OD and $70 \mu \mathrm{m}$ ID (Polymicro Technologies, Phoenix, Ariz., USA) was inserted into PE20 tubing (Clay Adams, Becton Dickinson, Franklin Lakes, N.J., USA), leaving $\sim 1 \mathrm{~cm}$ of silica exposed. Dialysis tubing with a molecular weight limit of $18,000 \mathrm{kDa}$ (Spectrum Laboratories, Rancho Dominguez, Calif., USA) was placed over the end of the silica and into the PE10 tubing and secured with epoxy. The open end of the dialysis membrane was sealed with an epoxy plug, leaving an active area of $\sim 2 \mathrm{~mm}$ for solute exchange across the membrane. Recovery rates for dopamine were determined for each probe before use and averaged $16.04 \pm 0.98 \%$.

Eight mice were anesthetized with 2,2,2-tribromoethanol and positioned in a stereotaxic apparatus equipped with a mouse adapter (Stoelting, Wood Dale, Ill., USA). The microdialysis probe was implanted in the striatum (+0.6 AP $,+1.7 \mathrm{ML}, 4.5 \mathrm{DV})$ according to an atlas of the mouse brain [Paxinos and Franklin, 2001]. A drop of Superglue (Ross Inc., Columbus, Ohio, USA) was applied to the skull and the probe was secured with dental cement (Lang Dental Manufacturing Co., Wheeling, Ill., USA). After surgery, the probe was connected to a microinjection pump (Harvard Apparatus, Holliston, Mass., USA) with a liquid swivel (Instech Laboratories, Plymouth Meeting, Pa., USA) and perfused continuously with artificial cerebrospinal fluid (147 mM NaCl, 3.5 mM KCl, $1.2 \mathrm{~m} M$ $\mathrm{CaCl}_{2}, 1.2 \mathrm{~m} M \mathrm{MgCl}_{2}, 1 \mathrm{~m} M \mathrm{NaH}_{2} \mathrm{PO}_{4}, 25 \mathrm{~m} M \mathrm{NaHCO}_{3}, \mathrm{pH}$ 7.0-7.4) at a flow rate of $1.5 \mu \mathrm{l} / \mathrm{min}$. Microdialysis samples were collected $14-16 \mathrm{~h}$ after surgery using $0.65-\mathrm{ml}$ polypropylene tubes containing $5 \mu \mathrm{l}$ of the artificial cerebrospinal fluid supplemented with $1.75 \mu M$ ascorbic acid as a preservative. The sampling interval was $20 \mathrm{~min}$. The first sample was discarded and the next 4 samples were collected as baseline. Further samples were collected after sequential treatment with vehicle, $4 \mathrm{mg} / \mathrm{kg} \pm$ BayK 8644 , and $4 \mathrm{mg}$ / $\mathrm{kg}$ amphetamine. All samples were immediately frozen and stored for HPLC analysis of monoamines. Data were corrected for probe recovery rates and analyzed using a paired t test to compare drug treatments with baseline. The location of the probe was verified by histological examination of the brain and by verifying the expected increase in dopamine after amphetamine.

\section{\pm BayK 8644 Behaviors in Mice}

To assess the role of presynaptic dopamine stores, behavioral responses to \pm BayK 8644 were evaluated in DD mutant mice and in mice with partial 6OHDA lesions of the dopamine pathways. The 6OHDA lesions were performed as previously described [Visser et al., 2002]. In brief, 20 mice between 4-5 weeks of age were treated subcutaneously with $20 \mathrm{mg} / \mathrm{kg}$ desipramine to block uptake of the toxin into noradrenergic neurons. Approximately 30-40 min later, they were anesthetized with inhaled methoxyflurane. The nape of the neck was shaved, and a 5-mm incision made at the occiput. A 27-gauge needle was inserted 2-3 mm and used to deliver $75 \mu \mathrm{g}$ of 6OHDA freshly dissolved in $0.9 \%$ saline with $0.01 \%$ ascorbic acid into the 4th ventricle. Another group of 20 mice, treated in parallel with subcutaneous desipramine and intracisternal vehicle, served as controls. Wounds were treated with Tritop analgesic and antiseptic ointment, and closed with cyanoacrylate tissue adhesive (Veterinary Laboratory Products, Phoenix, Ariz., USA).

A 2-week recovery period was allowed before behavioral testing with \pm BayK 8644 . The animals usually recovered normal ingestive behaviors within $24 \mathrm{~h}$, and they appeared behaviorally normal within 1-2 weeks. One control animal was excluded from the final analysis because of failure to resume normal motor behaviors.

Dystonia was defined as abnormal motor behavior characterized by torsional movements leading to odd postures and was evaluated as previously described [Jinnah et al., 2000]. Animals were placed singly in clear plastic chambers and observed for $1 \mathrm{~min}$ every $10 \mathrm{~min}$ for an hour. The severity of the motor disorder was rated on a 4-point scale at each recording interval, and all 6 scores were averaged to yield a single score for each animal. Results were compared via two-way ANOVA, with post-hoc Tukey t tests where appropriate.

SB and SIB were also evaluated as previously described [Kasim et al., 2002; Kasim and Jinnah, 2003]. SB was defined as biting any portion of the body without tissue injury, while SIB was defined as biting that resulted in tissue injury. SIB was terminated whenever it occurred by immediate anesthetization with methoxyflurane followed by $10 \mathrm{mg} / \mathrm{kg}$ subcutaneous nifedipine to prevent unnecessary pain or suffering. 
Several pilot studies were conducted to determine the best methods for scoring and analyzing SB and SIB, taking into consideration the requirement for immediate termination of SIB when it occurred. As a result of the frequent precipitous development of SIB, it was not feasible to employ rating scales for the degree of tissue injury analogous to those used in other studies where the behavior evolves more slowly [Kies and Devine, 2004]. The latency to onset of the behaviors provided too much variation, and the duration of the behaviors could not be used because of the requirement for termination of SIB as soon as it occurred [Kasim and Jinnah, 2003]. The most direct approach involved determining the total number of animals displaying either behavior but suffered two limitations. First, recording an all-or-none score obscured subtle differences in the severity of the behaviors. Second, the resultant data required analysis with relatively insensitive nonparametric statistics for categorical measures. This type of analysis increases the risk of missing important differences.

Ultimately, a two-step process was used. For SB, a time sampling procedure was used to estimate the percentage of time the behavior occurred during the test session. In brief, animals were monitored for $1 \mathrm{~min}$ every $10 \mathrm{~min}$ for an hour for SB. The 6 observation periods were then averaged to provide an estimate of the percentage of time SB occurred [Kasim et al., 2002; Kasim and Jinnah, 2003]. Dose-response profiles were compared by two-way ANOVA with post-hoc Tukey t tests where appropriate.

The time sampling method could not be used for SIB, since this behavior had to be stopped as soon as it occurred. SIB was directly recorded as a categorical variable and analyzed using the $\chi^{2}$ statistic for nonparametric measures. The combination of percent time for SB and the frequency of progression to SIB provided a close quantitative approximation for both frequency and severity of the behavioral manifestations.

At the conclusion of behavioral testing, the extent of 6OHDA lesions was confirmed by measuring dopamine and its metabolites in dissected caudoputamen from all animals [Visser et al., 2002]. Monoamines were measured by HPLC (ESA, Chelmsford, Mass., USA) with an array of electrochemical detectors set at 150, 250, 450, and $550 \mathrm{mV}$ [Jinnah et al., 1999a]. The samples were injected directly onto a $\mathrm{C} 18$ reverse-phase MD-150 column and eluted over a 24-min period at a flow rate of $0.6 \mathrm{ml} / \mathrm{min}$ with an isocratic solvent consisting of $1.7 \mathrm{~m} M$ 1-octanesulfonic acid sodium, $25 \mu M$ EDTA, $0.01 \%$ triethylamine, and $8 \%$ acetonitrile in $75 \mathrm{~m} M$ sodium phosphate buffer, $\mathrm{pH}$ 2.9. Dopamine and its metabolites were identified and quantified by means of simultaneous standards. Results for each metabolite were compared using Student's t test.

\section{\pm BayK 8644 Behaviors in Rats}

To further address the potential contributions of presynaptic dopamine stores, behavioral responses to \pm BayK 8644 were evaluated in rats with near-total 6OHDA lesions of dopamine systems during early development. Pregnant Sprague-Dawley rats were obtained from Harlan (Indianapolis, Ind., USA) and maintained at the University of North Carolina with free access to food and water. 6OHDA lesions were performed as previously described [Papadeas et al., 2004]. Briefly, male and female neonatal rats at 3-5 days of age were first pre-treated with $20 \mathrm{mg} / \mathrm{kg}$ desipramine subcutaneously to block uptake of the toxin into noradrenergic neurons. Approximately $60 \mathrm{~min}$ later they were anesthetized with ether and given intracisternal injections of $100 \mu \mathrm{g}$ of 6OHDA (free base) freshly dissolved in $10 \mu \mathrm{l}$ of saline with $0.01 \%$ ascorbic acid as a preservative. This treatment results in $>95 \%$ loss of dopamine and its axons in the striatum [Papadeas et al., 2004]. Sham-lesioned controls were treated similarly except the 6OHDA was omitted from the vehicle. One vehicle-treated control died after surgery and was not further evaluated.

The pups were weaned at 30 days of age, and behavior testing was performed at 35 days of age. Behavioral observations in rats were conducted using a modification of the methods used in mice. The rats were observed for $5 \mathrm{~min}$ every $15 \mathrm{~min}$ for a total of $80 \mathrm{~min}$. During each observation period, continuous recordings were made of the time animals engaged in SB. The time spent SB per period was averaged across all rats. The severity of dystonia was scored only during the first minute of each observation period.

\section{Drug-Induced Motor Activity}

To assess the roles of postsynaptic dopamine receptors, \pm BayK 8644 behaviors were evaluated after pretreating mice with one of several receptor antagonists. To verify that the drugs were not causing nonspecific sedation that might interfere with behavioral assessments, suppression of locomotor activity was investigated first with automated activity chambers [Jinnah et al., 1992]. The chambers consisted of $20 \times 40 \mathrm{~cm}$ Plexiglas boxes with 4 infrared beams spanning the short axis and 8 infrared beams spanning the long axis (San Diego Instruments, www.sd-inst.com). Unless otherwise noted, mice were placed singly in the chambers 15-20 min after receiving a test drug during their dark phase when they are normally most active. Beam breaks were recorded automatically by computer every $10 \mathrm{~min}$ with no habituation period for $2 \mathrm{~h}$.

\section{Results}

\section{Microdialysis}

Dopamine in striatal microdialysates was measured to determine if \pm BayK 8644 induced striatal dopamine release. No abnormal behaviors were observed in any of 8 mice after treatment with vehicle. After $4 \mathrm{mg} / \mathrm{kg} \pm$ BayK 8644 , all displayed dystonia and SB, with 6 progressing to SIB. However, there was no apparent increase in dopamine or its metabolites in the microdialysis samples after injection of \pm BayK 8644 (fig. 1).

The location of the probe within the striatum was verified histologically in each case (fig. 2). To verify that the microdialysis probes were capable of measuring an increase in dopamine release, microdialysis samples were also collected for $60 \mathrm{~min}$ from half of the animals after treatment with $4 \mathrm{mg} / \mathrm{kg}$ amphetamine following \pm BayK 8644. In each case, amphetamine provoked a significant increase in dopamine (fig. 1). These results provide evidence against the proposal that the behavioral consequences of \pm BayK 8644 are due to a massive dopamine release in the striatum. 


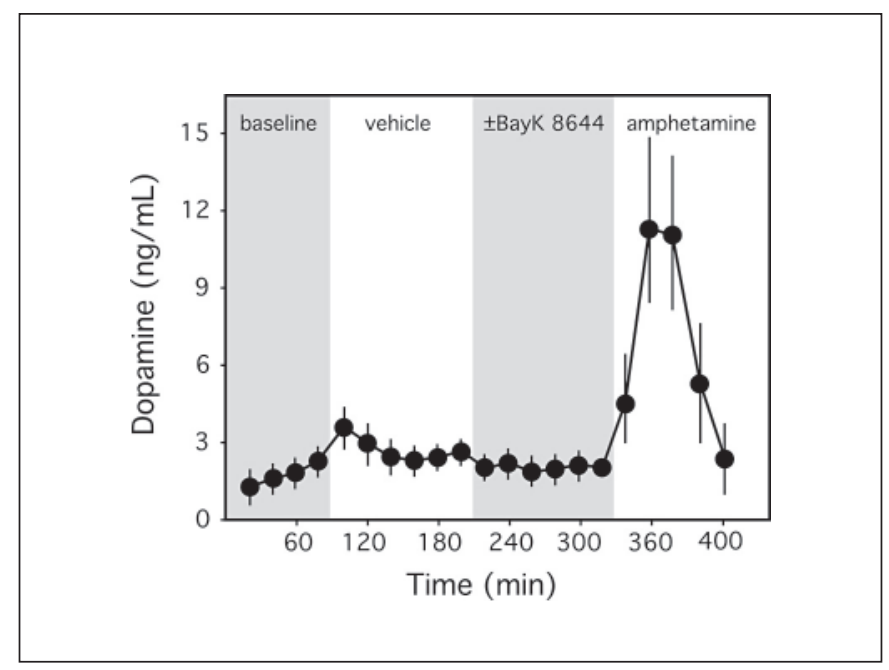

Fig. 1. Striatal microdialysates after \pm BayK 8644 or amphetamine. Average dopamine values \pm SEM are shown for 4-8 mice per sampling interval. Drug treatments were given once subcutaneously at the start of each epoch, depicted by shades of gray. A paired $t$ test was used to compare an average of the first 40 min after treatments (when the most prominent behavioral abnormalities were occurring) with average $40 \mathrm{~min}$ of baseline. There were no significant differences between baseline, vehicle, and \pm BayK 8644 treatment. However, there was a significant difference between baseline and amphetamine treatment $(\mathrm{p}<0.001)$.

\section{OHDA-Treated Mice}

The behavioral responses of mice with partial 6OHDAinduced lesions of brain dopamine systems were assessed to further clarify the role of dopamine. The rationale was that if \pm BayK 8644 caused its behavioral effects by provoking dopamine release, then the 6OHDA-lesioned mice should exhibit attenuated responses because they have lower dopamine stores. The goal was to assess behavioral responses in mice with partial 6OHDA lesions, because more severe lesions cause impairments that might interfere with the interpretation of responses provoked by \pm BayK 8644 .

Mice were given intracisternal 6OHDA at 4-5 weeks of age, and behavioral testing with \pm BayK 8644 was conducted after recovery from the lesions at 6-8 weeks of age. Because SB and particularly SIB are more prominent in weanling mice in comparison to adults [Jinnah et al., 1999b], the allowance of a 2-week recovery period led to relatively low rates of SIB in this experiment (table 1). In comparison with mice treated in parallel with vehicle, however, the 6OHDA had no apparent effect on the ability of \pm BayK 8644 to cause either SB or SIB (table 1).

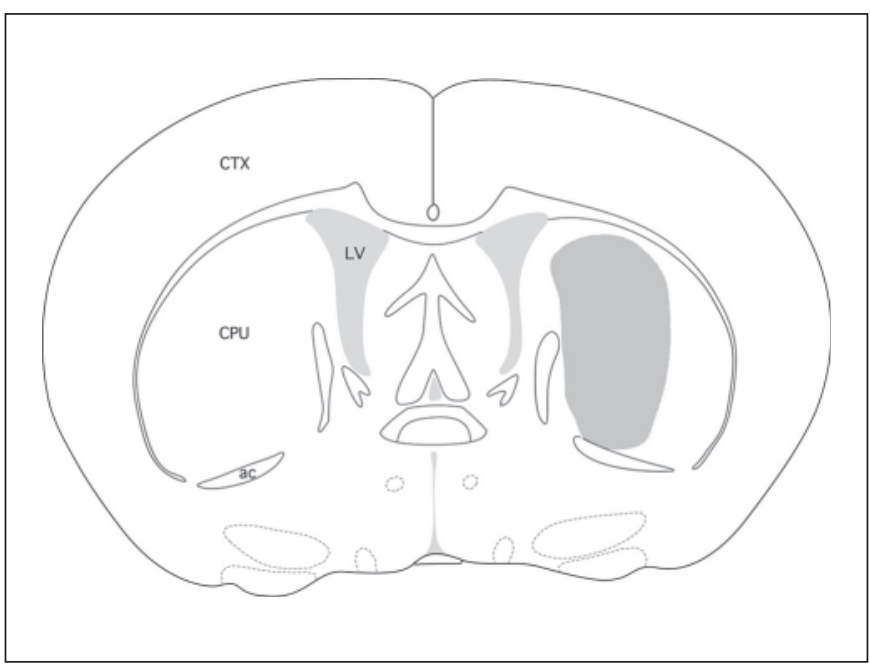

Fig. 2. Location of microdialysis probes. The target was AP 0.6, ML 1.7, and DV 4.5 according to a mouse atlas [Paxinos and Franklin, 2001]. The active zone of all probes fell within the stippled region shown. $\mathrm{CPU}=$ Caudoputamen, $\mathrm{CTX}=$ cortex, ac $=$ anterior commissure, $\mathrm{LV}=$ lateral ventricle.

Table 1. \pm BayK 8644 in 6 OHDA-lesioned mice

\begin{tabular}{lrll}
\hline Treatment group & \multicolumn{1}{l}{ SB } & SIB & Dystonia \\
\hline Control & & & \\
$2 \mathrm{mg} / \mathrm{kg}$ & $0.9 \pm 0.9$ & $0 / 19$ & $1.5 \pm 0.1$ \\
$4 \mathrm{mg} / \mathrm{kg}$ & $29.0 \pm 7.6$ & $1 / 19$ & $1.7 \pm 0.1$ \\
$8 \mathrm{mg} / \mathrm{kg}$ & $53.5 \pm 7.2$ & $2 / 19$ & $2.0 \pm 0.1$ \\
\hline 6 OHDA lesioned & & & \\
$2 \mathrm{mg} / \mathrm{kg}$ & $0.8 \pm 0.9$ & $0 / 20$ & $1.7 \pm 0.1$ \\
$4 \mathrm{mg} / \mathrm{kg}$ & $24.2 \pm 5.5$ & $0 / 20$ & $1.8 \pm 0.1$ \\
$8 \mathrm{mg} / \mathrm{kg}$ & $53.3 \pm 5.5$ & $1 / 20$ & $2.3 \pm 0.1 *$ \\
& & &
\end{tabular}

Results for SB reflect average percentage of time the behavior was observed \pm SEM for 19 mice in the vehicle-treated group and 20 mice in the 6OHDA-treated group. These results were analyzed by two-way ANOVA with 6OHDA treatment and \pm BayK 8644 dose as main factors. This analysis revealed a significant effect for \pm BayK 8644 dose $\left(F_{2,111}=51.5, p<0.0001\right)$. There was no significant effect for 6OHDA treatment $\left(\mathrm{F}_{1,111}=0.2, \mathrm{p}=0.7\right)$ and with no significant interaction $\left(\mathrm{F}_{2,111}=0.1, \mathrm{p}=0.9\right)$. Results for SIB reflect number of animals displaying the behavior compared with the total number of animals observed. These data were not subject to statistical analysis because of the small number of responders. Results for dystonia reflect average motor scores and were analyzed by two-way ANOVA with 6OHDA treatment and \pm BayK 8644 dose as main factors. This analysis revealed a significant effect for 6OHDA treatment $\left(\mathrm{F}_{1,111}=6.4, \mathrm{p}=0.013\right)$ and \pm BayK 8644 dose $\left(F_{2,111}=16.2, p<0.0001\right)$, with no significant interaction $\left(\mathrm{F}_{2,111}=0.6, \mathrm{p}=0.6\right)$. Significant difference from corresponding control group at each dose by post-hoc Tukey t test $(\mathrm{p}<0.05)$. 
Table 2. Striatal monoamines in 6OHDAlesioned mice

\begin{tabular}{lclll}
\hline Treatment group & Dopamine & DOPAC & HVA & 3MT \\
\hline Control $(\mathrm{n}=19)$ & $142.0 \pm 6.6$ & $7.3 \pm 0.3$ & $13.1 \pm 0.6$ & $8.8 \pm 0.4$ \\
6OHDA lesioned $(\mathrm{n}=20)$ & $60.0 \pm 5.4^{*}$ & $3.7 \pm 0.2^{*}$ & $6.8 \pm 0.3^{*}$ & $5.9 \pm 0.3^{*}$ \\
\hline
\end{tabular}

Results depict average values \pm SEM in $\mathrm{ng} / \mathrm{mg}$ protein. * A 2-tailed $\mathrm{t}$ test revealed a significant difference $(\mathrm{p}<0.01)$ for each metabolite.
Table 3. \pm BayK 8644 in DD mutant mice

\begin{tabular}{lccc}
\hline Treatment group & SB & SIB & Dystonia \\
\hline Control & & & \\
$2 \mathrm{mg} / \mathrm{kg}$ & $4.2 \pm 2.9$ & $0 / 8$ & $1.2 \pm 0.1$ \\
$4 \mathrm{mg} / \mathrm{kg}$ & $20.8 \pm 6.5$ & $0 / 8$ & $1.9 \pm 0.1$ \\
$8 \mathrm{mg} / \mathrm{kg}$ & $43.8 \pm 15.8$ & $2 / 8$ & $2.3 \pm 0.2$ \\
\hline $\mathrm{DD} \mathrm{mutants}$ & & & \\
$2 \mathrm{mg} / \mathrm{kg}$ & $4.2 \pm 2.9$ & $0 / 8$ & $2.2 \pm 0.1^{*}$ \\
$4 \mathrm{mg} / \mathrm{kg}$ & $39.6 \pm 10.6$ & $2 / 8$ & $3.0 \pm 0.2^{*}$ \\
$8 \mathrm{mg} / \mathrm{kg}$ & $70.8 \pm 12.9^{*}$ & $4 / 8$ & $3.4 \pm 0.1^{*}$ \\
\hline
\end{tabular}

Results for SB reflect average percentage of time the behavior was observed \pm SEM for 8 mice per group. These results were analyzed by two-way ANOVA with genotype and \pm BayK 8644 dose as main factors. This analysis revealed a significant effect for both genotype $\left(\mathrm{F}_{1,42}=4.1, \mathrm{p}<0.05\right)$ and dose $\left(\mathrm{F}_{2,42}=16.5, \mathrm{p}<\right.$ $0.001)$, with no significant interaction $\left(\mathrm{F}_{2,42}=1.1, \mathrm{p}>0.10\right)$. Results for SIB reflect number of animals displaying the behavior compared with the total number of animals observed. These data were analyzed by the $\chi^{2}$ statistic, and revealed no significant differences between the genotypes $\left(\chi^{2}=1.2, p=0.27\right)$. Results for dystonia reflect average motor scores and were analyzed by two-way ANOVA with genotype and \pm BayK 8644 dose as main factors. This analysis revealed a significant effect for both genotype $\left(\mathrm{F}_{1,42}=75.8, \mathrm{p}<\right.$ $0.001)$ and dose $\left(F_{2,42}=31.4, p<0.001\right)$, with no significant interaction $\left(F_{2,42}=0.01, p>0.10\right)$. Asterisks show significant differences from corresponding control group at each dose by post-hoc Tukey t tests $(\mathrm{p}<0.05)$.

On the other hand, 6OHDA slightly worsened motor disability scores.

Neurochemical assessment of the mice following behavioral testing revealed that 6OHDA treatment was successful in reducing striatal dopamine by an average of $58 \%$ compared to the vehicle-treated controls (table 2). All dopamine metabolites were similarly reduced by 6OHDA. These results are consistent with those from microdialysis in arguing against the proposal that the behavioral effects of \pm BayK 8644 result from dopamine release.

\section{DD Mice}

The behavioral responses of DD mutant mice were assessed to determine if more severe dopamine depletions might be required to attenuate behavioral responses to \pm BayK 8644 . These mice exhibit almost complete loss of striatal dopamine with profound hypoactivity, and they require daily L-DOPA supplements for survival. The DD mice were challenged with \pm BayK 8644 approximately $24 \mathrm{~h}$ after their last maintenance dose of L-DOPA, a time when residual dopamine stores are $<5 \%$ of normal and the animals typically demonstrate profound hypoactivity [Kim et al., 2000; Chartoff et al., 2001].

Despite their profound hypoactivity at the time of behavior testing with \pm BayK 8644 , the DD mice demonstrated significantly more SB in comparison with controls matched for age and sex (table 3). There was also a trend towards an increase in SIB that did not reach statistical significance. The DD mice also exhibited significantly higher motor disability scores than the control animals. Consistent with prior studies, neurochemical analyses of whole brains from the DD mice confirmed severe loss of brain dopamine with only $2 \%$ of normal levels (table 4 ). These results are consistent with those of the 6OHDA experiment in suggesting that release of presynaptic dopamine is not required for the behavioral effects of \pm BayK 8644 .

\section{OHDA Rats}

The behaviors induced by \pm BayK 8644 were also evaluated in rats with neurotoxin-induced depletion of striatal dopamine. Neonatal treatment with 6OHDA was chosen for two reasons. First, severe impairments of spontaneous motor behavior like those of the DD mice are absent in adult rats even with doses of 6OHDA that eliminate $>95 \%$ of residual striatal dopamine, provided that the lesions are made within the first few days after birth [Moy et al., 1997]. Residual endogenous dopamine is necessary for maintaining the relatively normal motor behavior, but the animals are behaviorally resistant to amphetamine and other dopamine-releasing agents [Cas- 
Table 4. Whole brain monoamines in DD mutant mice

\begin{tabular}{lclll}
\hline Treatment group & Dopamine & DOPAC & HVA & 3MT \\
\hline Control $(\mathrm{n}=10)$ & $63.4 \pm 2.4$ & $6.4 \pm 0.9$ & $13.8 \pm 1.8$ & $11.1 \pm 1.6$ \\
DD mutants $(\mathrm{n}=7)$ & $1.6 \pm 0.2^{*}$ & ND & $1.1 \pm 0.1$ & ND \\
\hline
\end{tabular}

Results depict average values \pm SEM in $n g / m g$ protein. * For dopamine, a 2-tailed $t$ test revealed $\mathrm{p}<0.0001$. Average HVA values were also low in the DD mice, but a formal statistical comparison was not conducted because 2 of 7 mice had undetectable levels $(<1 \mathrm{ng} / \mathrm{mg}$ protein). DOPAC and 3MT were not detectable in the DD mice. tenada et al., 1990]. Second, treated animals exhibit a well-characterized response that includes multiple stereotypic behaviors including SIB when repeatedly challenged as adults with L-DOPA or dopamine agonists [Breese et al., 1985].

Pilot studies in control animals indicated that rats were more sensitive and showed a very narrow dose-response profile to \pm BayK 8644 in comparison with mice. The test dose range was adjusted to reflect this species difference. The 6OHDA-lesioned rats exhibited significantly more SB and dystonia in comparison with the sham-lesioned group (table 5). SIB occurred in the 6OHDA-lesioned animals, but was absent from the shamlesioned controls. These results are consistent with those observed in mice with dopamine depletion and provide further support that presynaptic dopamine is not essential for the behavioral effects of \pm BayK 8644 .

\section{Locomotor Responses to Dopamine Receptor Antagonists}

The preserved behavioral responses of dopamine-depleted animals to \pm BayK 8644 suggest that the behavioral responses are not dependent upon presynaptic dopamine release. Instead, the sometimes enhanced sensitivity to the drug suggests the possibility of postsynaptic supersensitivity. To assess the role of postsynaptic dopamine receptors, the behavioral responses to \pm BayK 8644 were evaluated in mice pretreated with one of several antagonists selective for individual dopamine receptor subtypes. Because many of these antagonists cause sedation or hypoactivity that might interfere with interpreting behavioral responses to \pm BayK 8644 , the motor suppressive effects of the drugs were first evaluated for different doses of each antagonist, using the dose ranges delineated in prior studies [Bristow et al., 1997, 1998; Audinot et al., 1998; LaHoste et al., 2000].

Consistent with prior studies, the $\mathrm{D}_{1 / 5}$ antagonists SCH-23390 and SKF-83566 both caused a dose-depen-
Table 5. \pm BayK 8644 in 6 OHDA-treated rats

\begin{tabular}{lcll}
\hline Treatment group & SB & SIB & Dystonia \\
\hline Sham lesioned & & & \\
$1 \mathrm{mg} / \mathrm{kg}$ & $0.0 \pm 0.0$ & $0 / 5$ & $0.9 \pm 0.2$ \\
$2 \mathrm{mg} / \mathrm{kg}$ & $0.0 \pm 0.0$ & $0 / 10$ & $1.5 \pm 0.3$ \\
$3 \mathrm{mg} / \mathrm{kg}$ & $3.3 \pm 1.8$ & $0 / 10$ & $3.5 \pm 0.2$ \\
\hline 6 OHDA lesioned & & & \\
$1 \mathrm{mg} / \mathrm{kg}$ & $0.0 \pm 0.0$ & $0 / 5$ & $1.8 \pm 0.3^{*}$ \\
$2 \mathrm{mg} / \mathrm{kg}$ & $39.8 \pm 11.5^{*}$ & $2 / 15$ & $3.0 \pm 0.3^{*}$ \\
$3 \mathrm{mg} / \mathrm{kg}$ & $112.4 \pm 22.8^{*}$ & $3 / 8$ & $3.7 \pm 0.2$ \\
\hline
\end{tabular}

Results for SB reflect average number of seconds \pm SEM for each observation period. These results were analyzed by two-way ANOVA with lesion and \pm BayK 8644 dose as main factors. This analysis revealed a significant effect for lesion $\left(\mathrm{F}_{1,222}=16.8, \mathrm{p}<\right.$ $0.0001)$ and dose $\left(\mathrm{F}_{2,221}=8.3, \mathrm{p}<0.0005\right)$, as well as a significant interaction of dose and lesion $\left(\mathrm{F}_{2,218}=7.2, \mathrm{p}<0.001\right)$. Asterisks show significant differences from sham-lesioned rats at each dose as determined by Fisher's PLSD $(p<0.05)$. Results for SIB reflect number of animals displaying the behavior compared with the total number of animals observed. These data were analyzed by the $\chi^{2}$ statistic, which revealed a significant difference between the treatment groups $\left(\chi^{2}=4.9, p=0.026\right)$. Results for dystonia reflect average time-weighted motor scores and were analyzed by two-way ANOVA with lesion and \pm BayK 8644 dose as main factors. This analysis revealed a significant effect for lesion $\left(\mathrm{F}_{2,113}=16.6, \mathrm{p}<\right.$ $0.0001)$ and dose $\left(F_{1,112}=33.8, p<0.0001\right)$ as well as a significant interaction $\left(\mathrm{F}_{2,109}=3.3, \mathrm{p}<0.05\right)$.

dent suppression of motor behavior (fig. 3). Suppression of motor behavior by the $\mathrm{D}_{2}$ antagonist L-741,626 or the $\mathrm{D}_{3}$ antagonist GR-103691 was noted only at high doses (fig. 3). The $\mathrm{D}_{3}$ antagonist U-99194 increased motor behavior, while the $\mathrm{D}_{4}$ antagonist L-745,870 had no significant effect on motor behavior (fig. 3). None of the drugs caused SB, SIB, other oral stereotypies, or dystonic motor behavior. 

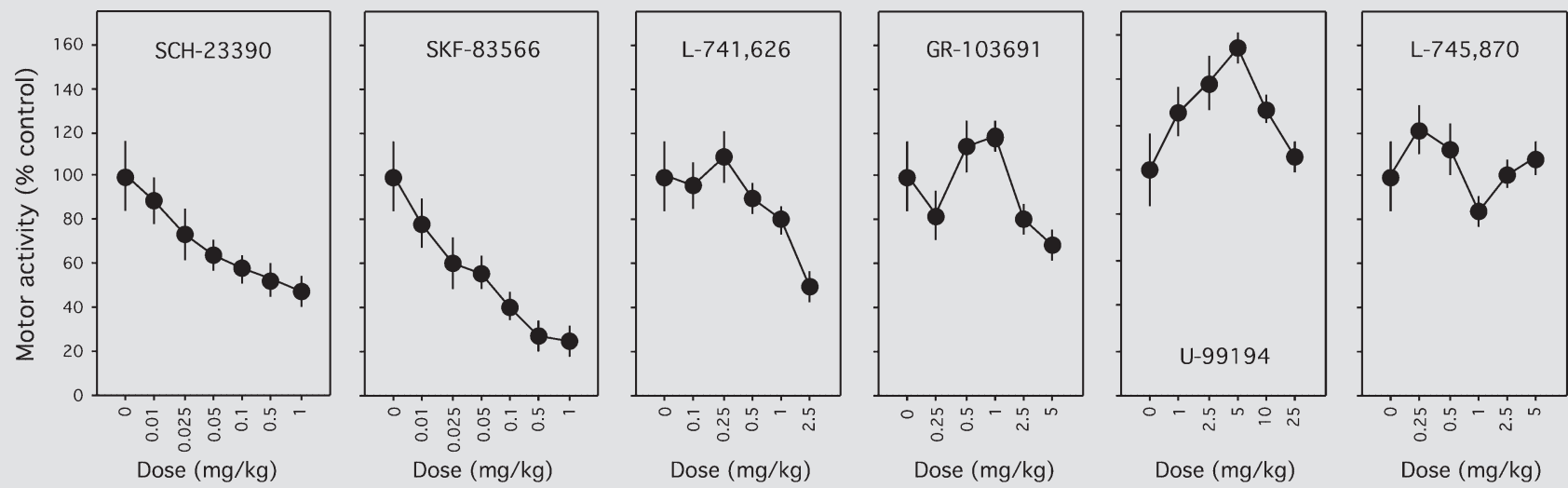

Fig. 3. Motor activity after pretreatment with dopamine receptor antagonists. All animals were naïve to the behavior apparatus and to the test drug. They were placed in the activity chambers without habituation 10-15 min following drug delivery, and total activity was recorded for $2 \mathrm{~h}$. Results show average values \pm SEM from 8 mice per drug dose.

\section{Dopamine Antagonists Modify Behavioral Responses to \pm BayK 8644}

The dose-response profiles for motor behavior were used to guide selection of the maximum doses of the antagonists while avoiding marked nonspecific suppression of motor behavior. Pretreatment with $0.1 \mathrm{mg} / \mathrm{kg} \mathrm{SCH}-$ 23390 significantly reduced both SB and SIB in response to \pm BayK 8644 (fig. 4), with no significant influence on motor disability scores. A higher pretreatment dose of $1 \mathrm{mg} / \mathrm{kg}$ further suppressed SB and SIB while increasing motor disability scores (not shown). Pretreatment with $0.1 \mathrm{mg} / \mathrm{kg}$ SKF-83566 significantly reduced SB and increased motor disability scores (fig. 4). There was a trend for reduced SIB that was not statistically significant. A higher pretreatment dose of $1 \mathrm{mg} / \mathrm{kg}$ significantly suppressed SB and SIB, and increased motor disability scores (not shown). These results provide evidence for involvement of $D_{1}$ and/or $D_{5}$ receptors in the behavioral actions of \pm BayK 8644. Pharmacological discrimination of which of these receptors might be most relevant is not possible because of the lack of subtype-specific antagonists.

Pretreatments with $1 \mathrm{mg} / \mathrm{kg}$ GR-103691 significantly reduced SB while slightly increasing motor disability scores in response to \pm BayK 8644 (fig. 4). Pretreatment with $10 \mathrm{mg} / \mathrm{kg}$ U-99194 also reduced SB but had no influence on motor disability scores. There was a trend for reduced SIB with both $\mathrm{D}_{3}$ antagonists, but this did not reach statistical significance. These results provide indirect evidence for involvement of $\mathrm{D}_{3}$ dopamine receptors in some of the behavioral actions of \pm BayK 8644 .

Pretreatment with $1 \mathrm{mg} / \mathrm{kg}$ of the $\mathrm{D}_{2}$ antagonist, L741,626 , had no significant influence on any of the behavioral consequences of \pm BayK 8644. Pretreatment with $1 \mathrm{mg} / \mathrm{kg}$ of the $\mathrm{D}_{4}$ antagonist, L-745,870, also had no significant effect. These results argue that $\mathrm{D}_{2}$ and $\mathrm{D}_{4}$ receptors do not play a role in the behavioral actions of \pm BayK 8644.

\section{Behavioral Responses of Dopamine Receptor}

Knockout Mice to \pm BayK 8644

To further assess the role of $\mathrm{D}_{3}$ dopamine receptors, behavioral responses to \pm BayK 8644 were evaluated in $\mathrm{D}_{3}$ receptor knockout mice. At baseline the $\mathrm{D}_{3}$ knockouts appeared physically and behaviorally normal as previously reported [Accili et al., 1996]. The behavioral responses of the $\mathrm{D}_{3}$ knockouts to \pm BayK 8644 were preserved but less pronounced than those of control mice matched for age, sex, and background genetic strain (table 6). SB and dystonia were both less prominent in the $\mathrm{D}_{3}$ knockouts. There was a trend for reduced SIB that did not reach statistical significance.

Similar studies of the role of $D_{1}$ receptors were conducted by assessing behavioral responses of $D_{1}$ receptor knockout mice to \pm BayK 8644 . The weanling $\mathrm{D}_{1}$ knockouts showed obvious signs of delayed physical develop- 


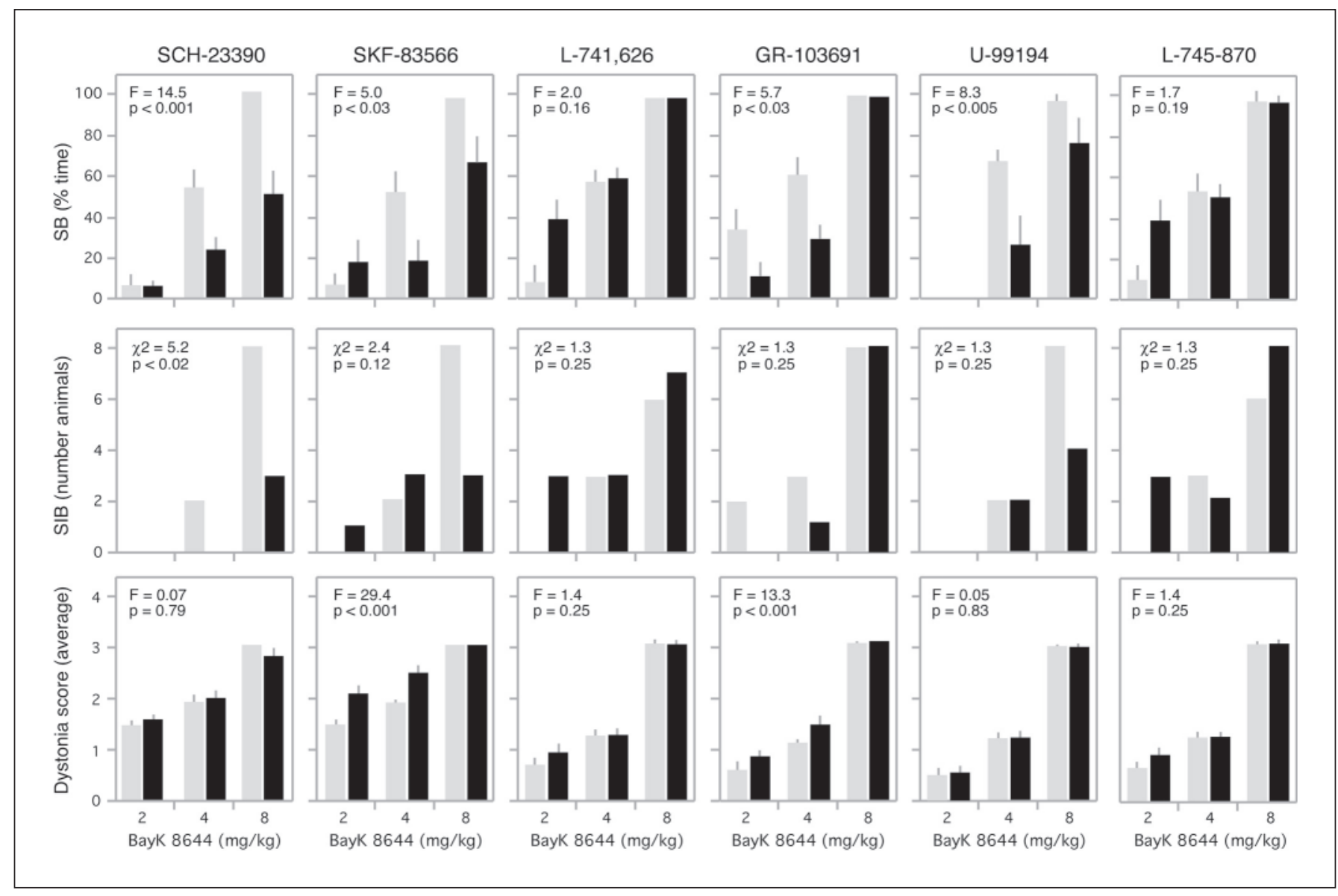

Fig. 4. \pm BayK 8644 behaviors after pretreatment with dopamine receptor antagonists. Drug-naïve animals were given a single pretreatment dose of the dopamine receptor antagonist indicated, or matched vehicle. In all cases the vehicle-treated control mice are shown as gray bars and the antagonist-pretreated mice are shown as black bars. Approximately $10 \mathrm{~min}$ later they were then challenged with one of three test doses of \pm BayK 8644 . Behavioral responses to \pm BayK 8644 after the antagonist were compared to the simultaneously pretreated vehicle group as described in the methods. The results of the statistical comparisons are indicated within each panel.

ment that could be attenuated with dietary supplements as previously described [Holmes et al., 2004]. However, the delay in physical development could not be eliminated during the ages required for behavioral testing with \pm BayK 8644 . The behavioral responses of the $\mathrm{D}_{1}$ knockouts to \pm BayK 8644 were preserved and often exaggerated. Quantitative assessments were not attempted, because the delay in physical development confounded the behavioral responses to \pm BayK 8644 , which are known to be critically dependent upon developmental status [Jinnah et al., 1999b].

\section{Discussion}

Activation of L-type calcium channels with \pm BayK 8644 causes dystonic motor behavior and SIB in young mice and rats. In prior studies, these behaviors have been linked with abnormalities of dopaminergic transmission in the striatum [Kasim and Jinnah, 2003]. The current studies confirm that dopaminergic pathways are involved in the expression of dystonia and self-injurious behaviors induced by \pm BayK 8644 . However, the influence of \pm BayK 8644 on dopaminergic transmission is not likely to be mediated at the presynaptic level, since microdialysis of the striatum provided no evidence for dopamine release after \pm BayK 8644 and behavioral responses were 
Table 6. \pm BayK 8644 in $\mathrm{D}_{3}$ knockout mice

\begin{tabular}{lccc}
\hline Treatment group & SB & SIB & Dystonia \\
\hline Control & & & \\
$2 \mathrm{mg} / \mathrm{kg}$ & $0 \pm 0$ & $0 / 10$ & $1.7 \pm 0.1$ \\
$4 \mathrm{mg} / \mathrm{kg}$ & $68.3 \pm 11.8$ & $5 / 10$ & $2.0 \pm 0.1$ \\
$8 \mathrm{mg} / \mathrm{kg}$ & $98.3 \pm 1.8$ & $8 / 10$ & $3.0 \pm 0.2$ \\
\hline $\mathrm{D}_{3} \mathrm{KO}$ & & & \\
$2 \mathrm{mg} / \mathrm{kg}$ & $2.1 \pm 2.2$ & $0 / 8$ & $1.2 \pm 0.2^{*}$ \\
$4 \mathrm{mg} / \mathrm{kg}$ & $41.7 \pm 13.0^{*}$ & $1 / 8$ & $1.8 \pm 0.2$ \\
$8 \mathrm{mg} / \mathrm{kg}$ & $89.6 \pm 7.5$ & $5 / 8$ & $3.0 \pm 0.1$ \\
\hline
\end{tabular}

Results for SB reflect average percentage of time the behavior was observed \pm SEM for 10 mice for each control group and 8 mice for each $\mathrm{D}_{3}$ knockout group. These results were analyzed by ANOVA with genotype and \pm BayK 8644 dose as main factors. The effect of genotype was borderline $\left(F_{1,48}=3.4, p=0.07\right)$. The effect of \pm BayK 8644 dose was significant $\left(F_{1,48}=81.0, p<0.001\right)$ but the interaction between genotype and \pm BayK 8644 was not $\left(\mathrm{F}_{2,48}=2.0, \mathrm{p}=0.2\right)$. Results for SIB reflect number of animals displaying the behavior. These data were analyzed by the $\chi^{2}$ statistic, which revealed no significant difference between the genotypes $\left(\chi^{2}=2.0, p=0.16\right)$. Results for dystonia reflect average motor scores and were analyzed by ANOVA with genotype and \pm BayK 8644 dose as main factors. There were significant effects for both genotype $\left(\mathrm{F}_{1,48}=6.7, \mathrm{p}<0.02\right)$ and \pm BayK 8644 dose $\left(\mathrm{F}_{2,48}=111.7\right.$, $\mathrm{p}<0.001)$, with a significant interaction for genotype $\mathrm{X} \pm$ BayK 8644 dose $\left(\mathrm{F}_{2,48}=3.3, \mathrm{p}<0.05\right)$. * Significant differences between genotypes at corresponding \pm BayK 8644 doses by post-hoc Tukey $\mathrm{t}$ tests $(\mathrm{p}<0.05)$.

preserved or even exaggerated in animals after near-total dopamine depletion. Instead, it seems more likely that the influence of \pm BayK 8644 is mediated by postsynaptic L-type channels.

It is interesting to note that acute depletion of dopamine with tetrabenazine or reserpine suppressed SB and SIB [Kasim and Jinnah, 2003], while more chronic depletion of dopamine after 6OHDA lesions had no effect on SB and SIB (table 2). The differing results cannot be explained by the degree of dopamine loss or species variations, since both studies employed mice and reached 50$60 \%$ depletion of total dopamine stores. More severe chronic dopamine depletions in the DD mutant mice and the neonatal 6OHDA-lesioned rats actually led to exaggerated SB and SIB in response to \pm BayK 8644 (tables 3,5$)$. These observations suggest that adaptive changes to severe chronic dopamine depletion, such as dopamine receptor supersensitivity, may increase susceptibility to SB and SIB. Indeed, dopamine receptor supersensitivity is thought to be a key feature of SB and
SIB that occurs after dopamine agonist treatment in rats with neonatal 6OHDA lesions [Moy et al., 1997].

Results of the current studies contradict those of two prior studies, which demonstrated $>100$-fold increase in rat striatal dopamine microdialysates after \pm BayK 8644 [Watanabe et al., 1998; Okita et al., 2000]. The discrepancy could reflect the different species used, the location of the microdialysis probe within the striatum, or the mode of drug delivery. Most notably, the current microdialysis studies were performed after subcutaneous drug delivery, while the prior study was conducted after direct intracerebral administration of the drug dissolved in dimethylsulfoxide. Regardless of the reasons for the differing results, the current studies showed no increase in striatal dopamine release under conditions where the behavioral effects were directly observed, demonstrating that the behavioral responses can be dissociated from any potential striatal dopamine release.

For the behaviors provoked by \pm BayK 8644 , the $\mathrm{D}_{3}$ dopamine receptor is implicated by the converging results showing that $\mathrm{D}_{3}$ dopamine receptor antagonists attenuate behavioral responses in normal mice, and by observations that $\mathrm{D}_{3}$ dopamine receptor knockout mice are less sensitive to the drug than normal controls. The $\mathrm{D}_{1}$ or $\mathrm{D}_{5}$ dopamine receptors are implicated by similar pharmacological studies using antagonists selective for $\mathrm{D}_{1 / 5}$ receptors. Though antagonists capable of discriminating these receptors are not available, the $\mathrm{D}_{1}$ receptor is more likely to be involved in these responses than the $\mathrm{D}_{5}$ receptor. The $\mathrm{D}_{1}$ receptor is heavily expressed in the striatum, it functionally interacts with L-type calcium channels, and it has been linked with a number of dopamine-related behavior [Hernandez-Lopez et al., 1997; Florez-Hernandez et al., 2002; Holmes et al., 2004]. Unfortunately, a specific role for $\mathrm{D}_{1}$ receptors could not be confirmed in $\mathrm{D}_{1}$ dopamine receptor knockouts because of their developmental delay.

Although the available results imply a role for $\mathrm{D}_{3}$ or $\mathrm{D}_{1 / 5}$ receptors in the expression of dystonia and $\mathrm{SB}$ after \pm BayK 8644 , the observation that these behaviors persisted under experimental conditions that reduce dopaminergic transmission via $D_{3}$ or $D_{1 / 5}$ receptors argues that neither receptor is required for expression of the behaviors. It remains possible that these different classes of receptors exhibit some redundancy of functions, requiring elimination of both to block behavioral responses to \pm BayK 8644 . It is equally plausible that these receptors modify behavioral responses to \pm BayK 8644 via an Ltype calcium channel, but that the receptors can be bypassed by direct activation of the channel. 
These results allow for a novel interpretation of the role of abnormal striatal dopamine transmission in the expression of dystonia and self-injurious behaviors. The basic striatal microcircuit consists of excitatory glutamatergic inputs on the heads of spines of medium spiny neurons, which constitute $95 \%$ of striatal neurons and the chief striatal output mechanism [for review, see Cepeda and Levine, 1998]. Dopaminergic inputs to the striatum modulate the efficacy of corticostriatal signaling via synapses onto the necks of the spines. The action of dopamine on individual medium spiny neurons is complex, as it can both stimulate or inhibit their activity. Dopamine enhances glutamateric excitation of medium spiny neurons via a mechanism that involves $\mathrm{D}_{1}$ receptor stimulation and enhanced calcium conduction via L-type calcium channels [Galarraga et al., 1997; Hernandez-Lopez et al., 1997; Cepeda and Levine, 1998]. Dopamine also inhibits glutamatergic excitation via a mechanism that involves $\mathrm{D}_{2}$ receptor stimulation and reduced L-type calcium conductances [Hernandez-Lopez et al., 2000; Yasumoto et al., 2004]. Normally, $\mathrm{D}_{1}$ and $\mathrm{D}_{2}$ receptors subserve separate and opposing striatal output pathways, acting in concert to facilitate intended behaviors while suppressing extraneous behaviors. The simultaneous and direct activation of L-type calcium channels in both pathways with \pm BayK 8644 may cause a disruption of the normal bal- ance of excitatory and inhibitory output thought to underlie dystonic motor behavior. The excessive presynaptic release of dopamine and/or overstimulation of supersensitive postsynaptic receptors thought to underlie self-injurious behaviors similarly might be replicated by direct activation of \pm BayK 8644-sensitive L-type calcium channels normally influenced by dopaminergic stimulation. In essence, the ability of dopamine to influence the expression of dystonia and SIB after \pm BayK 8644 and perhaps other situations is indirect, being related to its role as a neuromodulator of corticostriatal glutamatergic signaling.

While further studies will be required to evaluate the proposed roles of striatal dopamine and glutamate pathways in the expression of dystonia or SIB, the postulated role of L-type calcium channels in causing these behaviors leads to the prediction that inhibitors of these channels may be useful for these disorders.

\section{Acknowledgements}

This work was supported by NIH PHS grant HD39795. We thank Dr. Richard Mailman for generously providing $\mathrm{D}_{1}$ knockout breeders, and Dr. David Schretlen for advice on statistics.

\section{References}

Accili D, Fishburn CS, Drago J, Steiner H, Lacho- Breese GR, Baumeister AA, McCown TJ, Emerick wicz JE, Park B, Gauda EB, Lee EJ, Cool MH, Sibley DR, Gerfen CR, Westphal H, Fuchs S (1996): A targeted mutation of the D3 dopamine receptor gene is associated with hyperactivity in mice. Proc Natl Acad Sci USA 93: 1945-1949.

Audinot V, Newman-Tancredi A, Gobert A, Rivet JM, Brocco M, Lejeune F, Gluck L, Desposte I, Bervoets K, Dekyene A, Millan MJ (1998): A comparative in vitro and in vivo pharmacological characterization of the novel dopamine D3 receptor antagonist (+)-S 14297, nafadotride, GR 103,691 and U9914. J Pharmacol Exp Ther 287:187-197.

Berardelli A, Rothwell JC, Hallet M, Thompson PD, Manfredi M, Marsden CD (1998): The pathophysiology of primary dystonia. Brain 121:1195-1212.

Breese GR, Baumeister AA, McCown TJ, Emerick SG, Frye GD, Crotty K, Mueller RA (1984a): Behavioral differences between neonatal and adult 6-hydroxydopamine-treated rats to dopamine agonists: relevance to neurological symptoms in clinical syndromes with reduced brain dopamine. J Pharmacol Exp Ther 231: 343-354.
SG, Frye GD, Mueller RA (1984b): Neonatal6-hydroxydopamine treatment: model of susceptibility for self-mutilation in the Lesch-Nyhan syndrome. Pharmacol Biochem Behav 21: 459-461.

Breese GR, Baumeister A, Napier TC, Frye GD, Mueller RA (1985): Evidence that D-1 dopamine receptors contribute to the supersensitive behavioral responses induced by L-dihydroxyphenylalanine in rats treated neonatally with 6-hydroxydopamine. J Pharmacol Exp Ther 235:287-295.

Breese GR, Criswell HE, Duncan GE, Mueller RA (1990): A dopamine deficiency model of LeschNyhan disease - the neonatal 6-OHDA-lesioned rat. Brain Res Bull 25:477-484.

Breese GR, Criswell HE, Johnson KB, O'Callaghan JP, Duncan GE, Jensen KF, Simson PE, Mueller RA (1994): Neonatal destruction of dopaminergic neurons. Neurotoxicol 15:149-160.
Brien JF, Peachy JE, Rogers BJ, Kitney JC (1977): Amphetamine-induced stereotyped behaviour and brain concentrations of amphetamine and its hydroxylated metabolites in mice. J Pharm Pharmacol 29:49-50.

Bristow LJ, Collinson N, Cook GP, Curtis N, Freedman SB, Kulagowski JJ, Leeson PD, Patel S, Ragan CI, Ridgill M, Saywell KL, Tricklebank MD (1997): L-745,870, a subtype selective dopamine D4 receptor antagonist, does not exhibit a neuroleptic-like profile in rodent behavioral tests. J Pharmacol Exp Ther 283: 1256-1263.

Bristow LJ, Cook GP, Patel S, Curtis N, Mawer I, Kulagowski JJ (1998): Discriminative stimulus properties of the putative dopamine D3 receptor agonist, (+)-PD 128907: role of presynaptic dopamine D2 autoreceptors. Neuropharmacology 37:793-802.

pharmacology 37:793-802.
Castenada E, Whishaw IQ, Lermer L, Robinson TE (1990): Dopamine depletion in neonatal rats: effects on behavior and striatal dopamine release assessed by intracerebral microdialysis during adulthood. Brain Res 508:30-39.

Cepeda C, Levine MS (1998): Dopamine and Nmethyl-D-aspartate receptor interaction in the neostriatum. Dev Neurosci 20:1-18. 
-Chartoff EH, Marck B, Matsumoto AM, Dorsa DM, Palmiter RD (2001): Induction of stereotypy in dopamine-deficient mice requires striatal D1 receptor activation. Proc Natl Acad Sci USA 98:10451-10546.

Chaudieu I, Alonso R, Mount H, Quirion R, Boksa P (1992): Effects of L- and N-type Ca2+ channel antagonists on excitatory amino acidevoked dopamine release. Eur J Pharmacol 220:203-209.

Cromwell HC, Levine MS, King BS (1999): Cortical damage enhances pemoline-induced selfinjurious behavior in prepubertal rats. Pharmacol Biochem Behav 62:223-227.

-Florez-Hernandez J, Cepeda C, HernandezEcheagaray E, Calvert CR, Jokel ES, Fienberg AA, Greengard P, Levine MS (2002): Dopamine enhancement of NMDA curents in dissociated medium-sized striatal neurons: role of D1 receptors and DARPP-32. J Neurophysiol 88:3010-3020.

-Galarraga E, Hernandez-Lopez S, Reyes A, Barral J, Bargas J (1997): Dopamine facilitates striatal EPSP through an L-type $\mathrm{Ca} 2+$ conductance. Neuroreport 8:2183-2187.

Halladay AK, Kusnecov A, Hichna L, Kita T, Hara C, Wagner CC (2003): Relationship between methamphetamine-induced dopamine release, hyperthermia, self-injurious behavior and long term dopamine depletion in BALB/c and C57BL/6 mice. Pharmacol Toxicol 93:33-41.

Hernandez-Lopez S, Bargas J, Surmeier DJ, Reyes A, Galarrage E (1997): D1 receptor activation enhances evoked discharge in neostriatal medium spiny neurons by modulating an L-type $\mathrm{Ca} 2+$ conductance. J Neurosci 17:33343342.

-Hernandez-Lopez S, Tkatch T, Perez-Garci E, Galarraga E, Bargas J, Hamm H, Surmeier DJ (2000): D2 dopamine receptors in striatal medium spiny neurons reduce L-type $\mathrm{Ca} 2+$ currents and excitability via a novel PLCb1-IP3calcineurin-signaling cascade. J Neurosci 20: 8987-8995.

Holmes A, Lachowicz JE, Sibley DR (2004): Phenotypic analysis of dopamine receptor knockout mice; recent insights into the functional specificity of dopamine receptor subtypes. Neuropharmacol 47:1117-1134.

-Ichinose H, Ohye T, Takahashi E, Seki N, Hori T, Segawa M, Nomura Y, Endo K, Tanaka H, Tsuji S, Fujita K, Nagatsu T (1994): Hereditary progressive dystonia with marked diurnal fluctuation caused by mutation in the GTP-cyclohydrolase I gene. Nature Genet 8:232-242.

- Jankovic J (2005a): Dystonia and other deformities in Parkinson's disease. J Neurol Sci 239: $1-3$.

Jankovic J (2005b): Motor fluctuations and dyskinesias in Parkinson's disease: clinical manifestations. Mov Disord 20(suppl 11):S11-S16.

- Jinnah HA, Egami K, Rao K, Shin MY, Kasim S, Hess EJ (2004): Expression of c-fos in the brain after activation of L-type calcium channels. Dev Neurosci 25:403-411.

- Jinnah HA, Gage FH, Friedmann T (1990): Animal models of Lesch-Nyhan syndrome. Brain Res Bull 25:467-475.
Jinnah HA, Jones MD, Wojcik BE, Rothstein JD, Hess EJ, Friedmann T, Breese GR (1999a): Influence of age and strain on striatal dopamine loss in a genetic mouse model of Lesch-Nyhan disease. J Neurochem 72:225-229.

Jinnah HA, Langlais PJ, Friedmann T (1992): Functional analysis of brain dopamine systems in a genetic mouse model of Lesch-Nyhan syndrome. J Pharmacol Exp Ther 263:596-607.

- Jinnah HA, Sepkuty JP, Ho T, Yitta S, Drew T, Rothstein JD, Hess EJ (2000): Calcium channel agonists and dystonia in the mouse. Mov Disord 15:542-551.

Jinnah HA, Yitta S, Drew T, Kim BS, Visser JE Rothstein JD (1999b): Calcium channel activation and self-biting in mice. Proc Natl Acad Sci USA 96:15228-15232.

Kasim S, Egami K, Jinnah HA (2002): Self-biting induced by activation of L-type calcium channels in mice: serotonergic influences. Dev Neurosci 24:322-327.

Kasim S, Jinnah HA (2003): Self-biting induced by activation of L-type calcium channels in mice: dopaminergic influences. Dev Neurosci 25: 20-25.

Kies S, Devine DP (2004): Self-injurious behavior: a comparison of caffeine and pemoline in rats. Pharmacol Biochem Behav 79:587-598.

Kim DS, Szcypka MS, Palmiter RD (2000): Dopamine-deficient mice are hypersensitive to dopamine receptor agonists. J Neurosci 20:44054413.

King BH, Au D, Poland RE (1995): Pretreatment with MK-801 inhibits pemoline-induced selfbiting behavior in prepubertal rats. Dev Neurosci 17:47-52.

Kita T, Matsunari Y, Saraya T, Shimada K, O'Hara K, Kubo K, Wagner GC, Nakashima T (2000): Methamphetamine-induced striatal dopamine release, behavior changes, and neurotoxicity in BALB/c mice. Int J Dev Neurosci 18:521560.

LaHoste GJ, Henry BL, Marshall JF (2000): Dopamine D1 receptors synergize with $\mathrm{D} 2$, but not D3 or D4, receptors in the striatum without the involvement of action potentials. J Neurosci 20:6666-6671.

Lara-Lemus A, Mora MP, Mendez-Franco J, Palomero-Rivero M, Drucker-Colin R (1997): Effects of REM sleep deprivation on the d-amphetamine-induced self-mutilating behavior. Brain Res 770:60-64

Loupe PS, Bredmeier JD, Schroeder SR, Tessel RE (2002): Dopamine re-uptake inhibitor GBR12909 induction of aberrant behaviors in animal models of dopamine dysfunction. Int $\mathrm{J}$ Devel Neurosci 20:323-333.

Mink JW (2003): The basal ganglia and involuntary movements. Arch Neurol 60:1365-1368.

Moy SS, Criswell HE, Breese GR (1997): Differential effects of bilateral dopamine depletion in neonatal and adult rats. Neurosci Biobehav Rev 21:425-435.

Mueller K, Hollingsworth E, Pettit H (1986): Repeated pemoline produces self-injurious behavior in adult and weanling rats. Pharmacol Biochem Behav 25:933-938.
Mueller K, Nyhan WL (1982): Pharmacologic control of pemoline induced self-injurious behavior in rats. Pharmacol Biochem Behav 16:957963.

-Mueller K, Saboda S, Palmour R, Nyhan WL (1982): Self-injurious behavior produced in rats by daily caffeine and continuous amphetamine. Pharmacol Biochem Behav 17:613617.

Nausieda PA, Weiner WJ, Klawans HL (1980): Dystonic foot response of Parkinsonism. Arch Neurol 37:132-136.

Nordstrom O, Braisch-Andersen S, Bartfai T (1986): Dopamine release is enhanced while acetylcholine release is inhibited by nimodipine (Bay E 9736). Acta Physiol Scand 126:115119.

Nygaard TG, Marsden CD, Fahn S (1991): Doparesponsive dystonia: long-term treatment response and prognosis. Neurology 41:174181.

Okita M, Watanabe Y, Taya K, Utsumi H, Hayashi T (2000): Presynaptic L-type $\mathrm{Ca}^{2+}$ channels on excessive dopamine release from rat caudate putamen. Physiol Behav 68:641-649.

Page ME, Brown K, Lucki I (2003): Simultaneous analyses of the neurochemical and behavioral effects of the norepinephrine reuptake inhibitor reboxetine in a rat model of antidepressant action. Psychopharmacology 165:194-201.

-Papadeas ST, Blake BL, Knapp DJ, Breese GR (2004): Sustained extracellular signal-regulated kinase $1 / 2$ phosphorylation in neonate 6hydroxydopamine-lesioned rats after repeated D1-dopamine receptor agonist administration: implications for NMDA receptor involvement. J Neurosci 26:5863-5876.

Paxinos G, Franklin KBJ (2001): The mouse brain in stereotaxic coordinates, ed 2. San Diego, Academic Press.

Perlmutter JS, Mink JW (2004): Dysfunction of dopaminergic pathways in dystonia. Adv Neurol 94:163-170.

Schroeder SR, Oster-Granite ML, Berkson G, Bodfish JW, Breese GR, Cataldo MF, Cook EH, Crnic LS, Fisher W, Harris JC, Horner RH, Iwata B, Jinnah HA, King BH, Lauder JM, Lewis MH, Newell K, Nyhan WN, Rojahn J, Sackett GP, Sandman C, Symons F, Tessel RE, Thompson T, Wong DF (2001): Self-injurious behavior: gene, brain, behavior relationships. Mental Retard Dev Disabil Res Rev 7:3-12.

- Shishido T, Watanabe Y, Kato K, Horikoshi R, Niwa SI (2000): Effects of dopamine, NMDA, opiate, and serotonin-related agents on acute methamphetamine-induced self-injurious behavior in mice. Pharmacol Biochem Behav 66: 579-583.

-Sinnegger-Brauns MJ, Hetzenauer A, Huber IG, Renstrom E, Wietzorrek G, Berjukov S, Cavalli $\mathrm{M}$, Walter D, Koschak A, Waldschutz R, Hering S, Bova S, Rorsman P, Pongs O, Singewald N, Striessnig JJ (2004): Isoform-specific regulation of mood and behavior and pancreatic beta cell and cardiovascular function by L-type $\mathrm{Ca}^{2+}$ channels. J Clin Invest 113:14301439.
Kasim/Blake/Fan/Chartoff/Egami/ Breese/Hess/Jinnah 
Sivam SP (1995): GBR-12909-induced self-injurious behavior: role of dopamine. Brain Res 690 : 259-263.

-Skidmore F, Reich SG (2005): Tardive dystonia. Curr Treat Options Neurol 7:231-236.

-Surmeier DJ, Bargas J, Hemmings HC, Nairn AC, Greengard P (1995): Modulation of calcium currents by a D1 dopaminergic protein kinase/ phosphatase cascade in rat neostriatal neurons. Neuron 14:385-397.

- Turner C, Panksepp J, Bekkedal M, Borkowski C, Burgdorf J (1999): Paradoxical effects of serotonin and opioids in pemoline-induced self-injurious behavior. Pharmacol Biochem Behav 63:361-366.
Visser JE, Baer PR, Jinnah HA (2000): Lesch-Nyhan syndrome and the basal ganglia. Brain Res Rev 32:449-475.

Visser JE, Smith DW, Moy SS, Breese GR, Friedmann T, Rothstein JD, Jinnah HA (2002): Oxidative stress and dopamine deficiency in a genetic mouse model of Lesch-Nyhan disease. Dev Brain Res 133:127-139.

Watanabe Y, Lawlor GF, Fujiwara M (1998): Role of nerve terminal L-type $\mathrm{Ca}^{2+}$ channel in the brain. Life Sci 62:1671-1675.
Woodward JJ, Cook ME, Leslie SW (1988): Characterization of dihydropyridine-sensitive calcium channels in rat brain synaptosomes. Proc Natl Acad Sci USA 85:7389-7393.

Woodward JJ, Leslie SW (1986): Bay K 8644 stimulation of calcium entry and endogenous dopamine release in rat striatal synaptosomes antagonized by nimodipine. Brain Res 370: 397-400.

Yasumoto F, Negishi T, Ishii Y, Kyuwa S, Kuroda Y, Yoshikawa Y (2004): Dopamine receptor 2 regulates L-type voltage-gated calcium channel in primary cultured mouse midbrain neural network. Cell Mol Neurobiol 24:877-882.

\section{Letter to the Editor}

Dev Neurosci 2006;28:517

Since the publication of our manuscript 'Loss of notch activity in the developing central nervous system leads to increased cell death' in Development Neuroscience [1], we have discovered that the transgenic line Dlx5/6-Cre-IRES-EGFP displays elevated levels of cell death in the forebrain during embryogenesis (E12-E16) compared to control animals that lack this transgene. We used this $\mathrm{Cre}$ transgenic line to remove the Notchl gene in the ventral forebrain and published the observation that cell death was increased in the Dlx5/6-Cre;Notch 1 conditional knockouts [1; fig. 4C]. At this time we do not know whether the Dlx5/6-Cre;Notch 1 conditional knockouts have significantly more cell death than the Dlx5/6-Cre transgenics alone. However, it is clear that removing both the Notch1 and Notch 3 genes does lead to dramatically increased cell death compared to the Dlx5/6-Cre;Notch 1 single conditional knockout as well as the Dlx5/6-Cre transgenic.

\section{Reference}

1 Mason HA, Rakowiecki SM, Gridley T, Fishell G: Loss of notch activity in the developing central nervous system leads to increased cell death. Dev Neurosci 2006;28:49-57.

\section{Gord Fishell}

Developmental Genetics Program, Skirball Institute New York University School of Medicine 5501 st Avenue, New York, NY 10016 (USA) Tel. +1 212263 7691, Fax +1 2122632248

E-Mail fishell@saturn.med.nyu.edu 